\title{
Wykorzystanie nieużytków miejskich jako przestrzeni międzygatunkowych - analiza efektów wprowadzenia
}

\author{
Justyna Kleszcz \\ Katedra Architektury i Urbanistyki, \\ Wydziat Budownictwa, Architektury i Inżynierii Środowiska, Uniwersytet Zielonogórski, \\ e-mail:j.kleszcz@aiu.uz.zgora.pl
}

Streszczenie: Tereny nieużytków miejskich powstają najczęściej w dwojaki sposób. Mogą one stanowić tereny użytkowane ekstensywnie o różnorakiej etymologii lub, co istotniejsze, rodzaj artefaktów pozostałych po wymarłej w danym miejscu funkcji. Tereny te, jako powstające na granicy pomiędzy przestrzeniami o różnorakim przeznaczeniu, stanowią w głównej mierze o jakości lub bylejakości linii przejścia pomiędzy tym, co w mieście planowane, a pozostałymi terenami rozwijającymi się niejako obok, bez wyraźnego planu. Dodatkowo brak aranżacji tych miejsc powoduje podział miasta na szereg niespójnych fragmentów - zarówno pod względem funkcjonalnym, kompozycyjnym jak i estetycznym. Z tego powodu celem podjętych badań była analiza lokalizacyjna terenów mogących w przyszłości służyć uspójnieniu miejskich terenów pozostających bez wyraźnego zagospodarowania i ich czasowej adaptacji na cele rekreacyjne, integracyjne czy edukacyjne, służące docelowo mieszkańcom miast zarówno ludzkim, jak i zwierzęcym. Wprowadzenie przestrzeni międzygatunkowych jako konkretnego rozwiązania, sposobu przekształcania problematycznych przestrzeni miejskich, ma wpływ na zmianę sposobu funkcjonowania miasta zarówno jako organizmu, ekosystemu, jak i struktury urbanistycznej. Takie kształtowanie powoduje kumulowanie pozytywnych cech przekształceń miasta wzrostu jakości zielonych przestrzeni rekreacyjnych, terenów sportowych, poprawę bezpieczeństwa, odtwarzanie flory i fauny miejskiej i wiele innych.

Słowa kluczowe: przestrzenie międzygatunkowe, urbanistyka, architektura dla zwierząt, planowanie miast, zieleń miejska.

\section{Wprowadzenie}

Zagadnienie aranżacji nieużytków miejskich staje się coraz istotniejszym problemem w miastach polskich w okresie rosnącego "głodu" dobrze skomunikowanych, lecz tanich przestrzeni, które można przeznaczyć dla zaspokojenia rosnących potrzeb mieszkaniowych. Wprowadzenie idei poprawy jakości przestrzeni miejskich poprzez wprowadzenie ścisłej segregacji funkcji spowodowało powstanie rodzaju gett funkcjonalnych w ścisłych centrach. Wraz z rozwojem wyseparowanych przestrzennie stref funkcjonalnych w mieście narasta też problem zapewnienia mieszkańcom przynajmniej podstawowych funkcji uzupełniających, dopełniających zespoły mieszkaniowe. W takiej sytuacji coraz mniej przestrzeni pozostaje do zaaranżowania dla zwierząt, których obecność stosunkowo niedawno zaczęliśmy w sposób świadomy dostrzegać i wykorzystywać w celu poprawy jakości przestrzeni miejskiej w myśl zasad rozwoju zrównoważonego.

W przypadku analiz przeprowadzanych dla poszczególnych miast doprowadzi ona do zdiagnozowania i opisania sieci potencjalnych lokalizacji w oparciu o uwarunkowania lokalne oraz globalne. Ważnym aspektem staje się w tym przypadku określenie możliwości 
"intensywnej", społecznie użytecznej adaptacji terenów wykorzystywanych do tej pory w sposób ekstensywny, tak by zaczęły służyć lokalnym społecznościom poprzez wprowadzenie formy tymczasowej aranżacji na cele służące ludziom i zwierzętom mieszkającym we współczesnych miastach.

Współczesne przestrzenie międzygatunkowe, stanowiące miejsca obecności zwierząt w miastach, powstają bardzo często w sposób spontaniczny w miejscach bez ściśle określonej funkcji lub stanowią element wprowadzany na terenach zurbanizowanych niejako doświadczalnie, w celu sprawdzenia możliwości jego dalszego rozwoju, w obszarach o odmiennej funkcji. Podjęta na wstępie analiza istniejących form współużytkowania terenów przez ludzi i zwierzęta oraz możliwości włączenia ich w sieć powiązań tworzących przestrzenie integracyjne da podstawę do stworzenia pierwszych elementów potencjalnej sieci powiązań opartej na istniejącym układzie tych terenów, łączących w miastach przestrzenie o różnej genezie historycznej w spójną całość poprzez wprowadzenie nowej, dotąd niespotykanej funkcji.

W związku z tym istotne staje się przeprowadzenie analizy możliwości wykorzystania wybranych terenów pod kątem ich użyteczności na cele przyszłej adaptacji, jak również źródeł potencjalnych zagrożeń i ograniczeń w tym rozwoju, ale także zysków - również tych, które nie zostałyby uzyskane przy samodzielnym stosowaniu opisywanych metod. W opracowaniu wykorzystano w głównej mierze przykłady małych i średnich miast z okolic Zielonej Góry, w których istnieje możliwość wprowadzenia układu sieciowego terenów przeznaczonych dla ludzi i zwierząt łączącego w spójną całość Zieloną Górę oraz jej miasta satelickie.

Wykorzystanie jako metodę przekształceń - aranżację na nową funkcję miejsc dotychczas pomijanych ma szansę wpłynąć na pojawienie się interdyscyplinarności w rozwiązaniach i adaptacjach terenów historycznych dzielnic oraz ich nowocześniejszego lub niespójnego funkcjonalnie otoczenia, skupionych nie tylko na spójności historycznej, lecz również na jakości i sposobie funkcjonowania przestrzeni przeznaczonej pierwotnie do innych celów.

Podjęte zagadnienie składa się zasadniczo z dwóch elementów wymagających uszczegółowienia i sprecyzowania. Składa się na nie kwestia zdefiniowania pojęcia nieużytku miejskiego jako formy przestrzennej występującej na terenach zurbanizowanych jako konsekwencja rozwiniętego procesu suburbanizacji miasta lub też założonego, progresywnego strefowania funkcjonalnego.

\section{Miasto}

Bazując na tej definicji oraz na definicji użytków rolnych, stanowiącym jedno z pojęć $\mathrm{z}$ zakresu teorii urbanistyki ${ }^{1}$ na potrzeby niniejszej analizy przyjęto definicję nieużytku miejskiego.

Nieużytek miejski stanowi taki rodzaj zagospodarowania przestrzeni, który jest bezpośrednio związany z funkcjonowaniem miasta i leżącym w jego granicach, który na skutek działalności człowieka, lub na skutek zaniechania takowych działań utracił swoją pierwotną wartość użytkową. Przy tym sama idea miejskiego nieużytku nie zamyka jej formy jedynie do pojęcia gruntu położonego w granicach miasta. Nieużytkiem miejskim może być też budynek - pustostan, obiekt, którego program użytkowy już się wyczerpał i zdezaktualizo-

${ }^{1}$ użytek rolny - grunt związany bezpośrednio z produkcją rolną: grunty orne, sady i plantacje wieloletnie oraz użytki zielone - trwałe łąki i pastwiska, służące do produkcji paszy i wypasu bydła. [1]. 
wał. W skrajnych przypadkach mogą to być również tereny, które choć pełniące pewną określoną funkcję, są wykorzystywane w sposób ekstensywny albo ich potencjał jest znacznie większy, niż aktualny stan zagospodarowania.

Można zaobserwować, że ostatnimi czasy następuje powolne odejście od tradycyjnej definicji miasta, określanego jako "(...) historycznie uksztaltowany typ osiedla, wyznaczony istnieniem konkretnej społeczności czastkowej, skoncentrowanej na pewnym obszarze, o odrębnej organizacji, uznanej i określonej prawnie oraz wytwarzajacej $w$ ramach swej działalności zespót trwałych urządzeń materialnych o specyficznej fizjonomii, która odzwierciedla odrębny typ krajobrazu. (...)"'[2]

Jak zauważył to Krier [3] formuła miasta oparta na segregacji funkcjonalnej i strefowaniu z zapewnieniem jedynie funkcji produkcyjno-przemysłowej już się wyczerpała, czego dowodem jest postępująca degradacja i degeneracja struktur miejskich o tym charakterze. Jednym z rozwiązań, które przyjęto w celu poprawy sytuacji jest właśnie wprowadzenie zwartego, ciągłego systemu struktur zieleni miejskiej. Jednak warunkiem prawidłowego działania takiej sieci jest przeciwdziałanie jej izolacji, zarówno funkcjonalnej, jak i lokalizacyjnej. Dla zapewnienia ciągłości zieleni miejskiej plany sieci w skali regionu czy aglomeracji powinny być traktowane nadrzędnie i uwzględniać połączenia z drobniejszymi sieciami o znaczeniu lokalnym. Aby w praktyce została zrealizowana ich funkcja strukturotwórcza, konieczne jest powiązanie w nich funkcji ochronnych z rolnictwem, leśnictwem i rekreacją $[4,13]$.

\section{Nieużytki miejskie}

Na potrzeby niniejszego opracowania przyjęto definicję nieużytku miejskiego opracowanego na podstawie pojęć odnoszących się do formy nieużytku znanego z nauk geograficznych i ekologicznych. W założeniu podstawowym nieużytek to taki obszar - rodzaj gruntu, który z powodu naturalnych warunków siedliskowych lub na skutek działalności rolniczej przemysłowej, leśnej lub innej nie posiada lub utracił wartość użytkową. [5] W takim przypadku do nieużytków zaliczane są bagna, wydmy, tereny o niekorzystnym ukształtowaniu terenu, składowiska odpadów oraz grunty zdegradowane z powodu różnych czynników. W przyjętych założeniach ich zagospodarowanie, mające na celu przywrócenie funkcji tożsamych pierwotnym, to jest rolnej, czy leśnej staje się utrudnione ze względu na znaczny koszt oraz czasochłonność zabiegów rekultywacyjnych. Ich zagospodarowanie rolne, leśne lub inne jest trudne lub bardzo kosztowne ze względu na konieczność wykonywania odpowiednich zabiegów rekultywacyjnych, melioracyjnych, zalesień itp.

Jak wykaże dalsza analiza wybranych miast polskich sama kategoryzacja nieużytków miejskich, mimo pewnych ogólnych tendencji jest ściśle zależna od konkretnego przypadku i może być rozumiana w wieloraki sposób. W ogólnym ujęciu forma nieużytku miejskiego może w rzeczywistości być w pełni przekształcalna, może pełnić, mimo swojej "zadeklarowanej" bezfunkcyjności pewne wyznaczalne role. m.in.:

- bytowe (np. czasowe farmy, ogrody miejskie),

- rekreacyjne (np. parki, ścieżki, tymczasowe place zabaw),

- edukacyjne, artystyczne (np. miejsce instalacji artystycznych, performatywnych),

- zdrowotne (np. miejsca odbywania zajęć z zakresu zooterapii). 


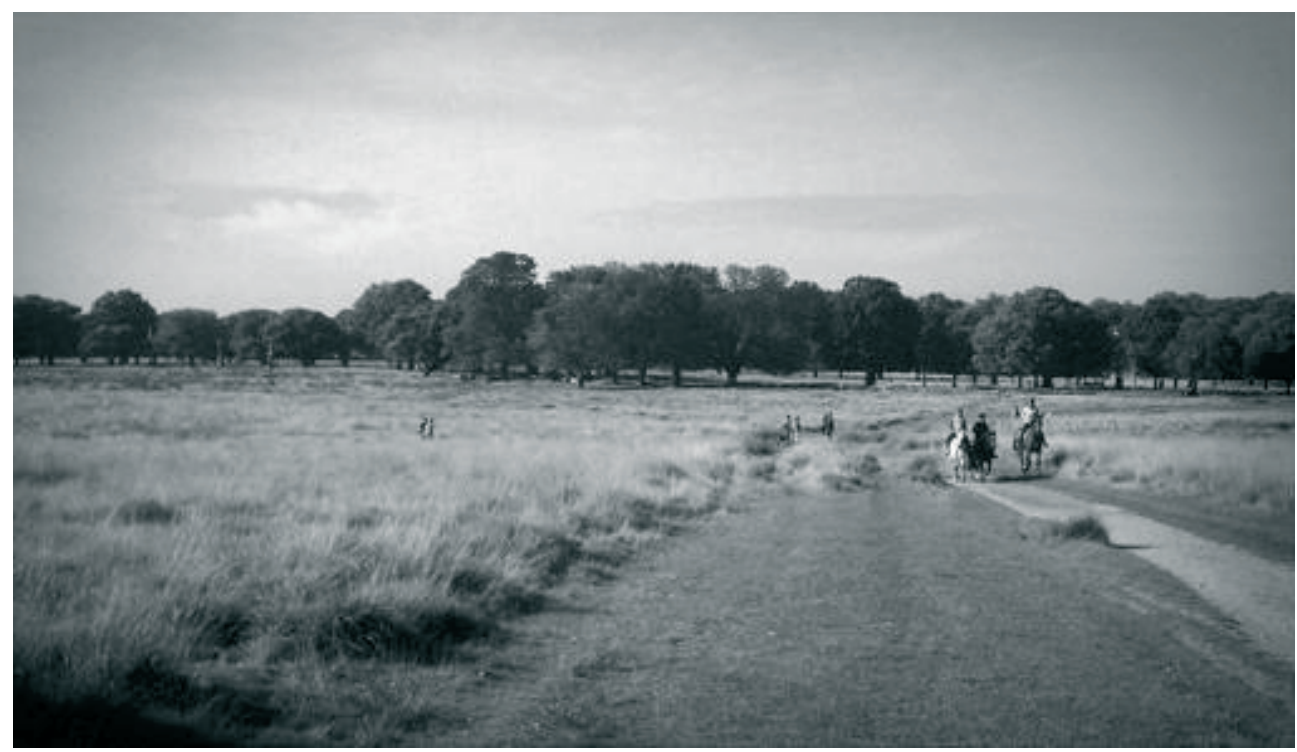

Rys. 1. Przestrzeń międzygatunkowa tworząca się samoistnie w największym w Europie ogrodzonym parku, powstałym pierwotnie jako rezerwat jeleni w Londynie. Park Richmond w Londynie, październik 2015

\section{Przestrzenie międzygatunkowe}

Przestrzeń międzygatunkowa jako nowe zjawisko w urbanistyce i przestrzeni architektonicznej jest pojęciem zaczerpniętym z pracy Edwarda Dodingtona dotyczącej kształtowania środowiska poshumanistycznego oraz stworzonego przez niego pojęcia parku wielogatunkowego.[6,7] Łącząc to pojęcia z zagadnieniami z zakresu biologii oraz ekologii otrzymujemy zespół cech, które po wprowadzeniu w życie tworzą formę zagospodarowania przestrzeni realizującą założenia nowej, strukturotwórczej formy zagospodarowania terenów zielonych. Postulując przy tym stworzenie otwartej sieci wzajemnie powiązanych przestrzeni o zmiennej funkcji, tworzy się obraz miasta, w którym jego programowana segregacja funkcjonalna dążąca do wydzielenia monogatunkowych monofunkcji w połączeniu $\mathrm{z}$ wyrugowaniem funkcji tradycyjnie uznawanych za ruralne ulega przekształceniu w ideowo wielofunkcyjną tkankę, która ulega dynamicznym zmianom i reaguje na cyklicznie zmieniające się zapotrzebowanie społeczne.

\subsection{Definicja}

W niniejszej pracy przyjęto definicję przestrzeni międzygatunkowej opracowanej przez autorkę podczas pracy nad rozprawą doktorską. Opierając się na pojęciu poly species architecture wprowadzonym przez Edwarda Dodingtona, które jednak odnosiło się jedynie do zagadnienia samej architektury opracowano pojęcie przestrzeni międzygatunowej, definiowanej jako rodzaj zagospodarowania terenu powstałego na styku pomiędzy terenami wytworzonymi i użytkowanymi przez człowieka, a terenami użytkowanymi przez zwierzęta. Może ona ukształtować się zarówno w sposób naturalny, jak i antropogeniczny na terenach leżących w granicach miast. W miejscach tych w sposób niewymuszony następuje proces integracji, jako współużytkowania przestrzeni na równych prawach przez wszystkie przebywające w niej gatunki, nie wyłączając człowieka, jako pierwotnego inicjatora jej powstania. 
W uproszczeniu przestrzenią międzygatunkową możemy nazwać każde miejsce świadomej interakcji pomiędzy zwierzętami a ludźmi, w której zwierzę jest traktowane jako współużytkownik miejsca, jego docelowy współodbiorca, a nie jedynie jako narzędzie służące człowiekowi do osiągnięcia pewnych konkretnych celów, bądź to zdrowotnych, edukacyjnych, rekreacyjnych czy kulturowych. Świadomie pominięto tu aspekt bytowy związany z pracą fizyczną zwierząt $\mathrm{i}$ ich znaczeniem dla wyżywienia ludzi, jako już u podstaw niemający wspólnych mianowników z pojęciem równości praw.

Niezmiernie istotnym aspektem $\mathrm{w}$ analizowaniu przestrzeni międzygatunkowych jako form przestrzennych jest ich ścisły związek z założeniami zieleni miejskiej i jej rozwojem w strukturach miasta. Przyjęcie za punkt bazowy dla poniższej analizy relacji miasto natura pozwala prześledzić historyczne i kulturowe zmiany, które umożliwiły powstanie bardziej zwartych relacji pomiędzy strukturami przeznaczonymi dla ludzi i zwierząt. Stanowi to punkt wyjściowy w rozważaniach na temat tworzenia się w miastach przestrzeni międzygatunkowych, ich genezy i możliwości zaistnienia w większych strukturach urbanistycznych jako trwały element układów sieciowych.

"Rodzaj przestrzeni miejskiej powstałej na styku pomiędzy terenami wytworzonymi i użytkowanymi przez człowieka, a terenami użytkowanymi przez zwierzęta zarówno w sposób naturalny, jak i antropogenicznymi, a leżacymi $w$ granicach miast, $w$ której, w sposób niewymuszony następuje proces integracji, jako współużytkowania przestrzeni na równych prawach przez wszystkie przebywajace w niej gatunki, nie wyłaczając człowieka, jako pierwotnego inicjatora jej powstania." [8]

\subsection{Przykłady}

Ze względu na konieczność zachowania wszelkich wymogów związanych zarówno z bezpieczeństwem każdego z użytkowników, jak i z koniecznością zapewnienia parametrów gwarantujących komfort i swobodę korzystania $\mathrm{z}$ miejsc dostosowanych do grupy użytkowników o skrajnie odmiennych wymaganiach przestrzennych, przestrzenie międzygatunkowe w ścisłym tego słowa znaczeniu powstają jedynie w formie parków lub terenów rekreacyjnych o znacznej powierzchni. Przykład aranżacji takich terenów stanowi wspomniany już amerykański park Garey w Georgetown w Teksasie.

Charakterystycznym elementem $\mathrm{w}$ tego typu inwestycjach jest zastosowanie maksymalnie dwóch ogólnodostępnych wejść stanowiących wydzieloną strefę wejściową, rodzaj strefy buforowej oddzielającej, przy pomocy układu bram zewnętrze od wnętrza wydzielonego obszaru. Ma to na celu w głównej mierze zwiększenie bezpieczeństwa przebywających wewnątrz osób i zwierząt poprzez kontrolę dostępu, jak również zapobieżenie niekontrolowanemu wydostaniu sie na zewnątrz dzieci czy zwierząt. Podobny zabieg przestrzenny powoduje również ograniczenie możliwego niekorzystnego wpływu na otoczenie, co zwiększa realnie odczuwalny poziom przyzwolenia społecznego na tego typu funkcje w najbliższym sąsiedztwie oraz podnosi poziom akceptacji dla zjawisk integracyjnych.

Ograniczoną formę przestrzeni międzygatunkowej stanowią również wspomniane trasy rekreacyjne pieszo- rowerowo - konne, rozpowszechnione zwłaszcza w krajach anglosaskich. Tworzone na podstawie wzorca dróg przygotowanych dla ruchu powozów, wzbogacone o elementy dostępne dla kolejnych użytkowników, posiadają również swoje niezależne ustawodawstwo ${ }^{2}$. Ze względu na liniowy charakter trasy takie posiadają szerszy zakres oddziaływania, tworząc wyraźny akcent w strukturze miejskiej. Łączą ze sobą elementy

${ }^{2}$ Przykładowo Design Manual For Roads And Bridges, Volume 6 Section 3 "Road Geometry Highway Features" Part 5 Ta 90/05 The Geometric Design Of Pedestrian, Cycle And Equestrian Routes, wydane przez Ministerstwo Transportu Wielkiej Brytanii. 
punktowe spełniające rolę komunikacyjną i redystrybuującą użytkowników oraz miejsca skumulowanej aktywności ludzi i zwierząt Poniższe przykłady zawierają analizę dwóch tego typu elementów zaprojektowanych i wdrożonych dla miasta Vancouver. Poszczególne trasy powstałe w powiązaniu terenami rekreacyjnymi miasta oraz siecią rzeczną. Stanowią doskonały przykład realizacji myśli o przestrzeni integracyjnej jako idei, wokół której można zbudować pomysł na realizację całościowego układu terenów rekreacyjnych w mieście. Większość założeń, które pojawiają się w warstwie ideowej bądź realizacyjnej w mniejszym lub większym stopniu nawiązuje do założeń howardowskiego miasta-ogrodu [9]. Sformułowana przez niego teoria była podstawą stworzenia i realizacji planu pierwszego miasta-ogrodu w miejscowości Letchworth pod Londynem, autorstwa Barrego Parkera i Raymonda Unwina. Opierająca się na głównej zasadzie stworzenia przestrzeni przyjaznej dla życia i rekreacji mieszkańców, idea stała się jednak początkiem idei miast satelickich, miast - sypialni, które zaczęły powstawać wokół największych światowych metropolii. $\mathrm{Z}$ drugiej jednak strony teoria ta stworzyła również podwaliny dla powstania idei hybrydowej formy wsi w mieście, permakulturealnego tworu powstającego jako element struktury miejskiej, jednak z drugiej strony całkowicie od niego oderwany, jak w przypadku nowej dzielnicy holenderskiego Almere - Oosterwold, zwany Agromere [10].

\section{Związek przestrzeni międzygatunkowych z pojęciem nieużytku miejskiego}

Choć nie jest to oczywiste, związek między przestrzeniami międzygatunkowymi powstającymi samoistnie, a rolą celowo lub nie powstających nieużytków jest jednoznaczna. Przykładem dobrze ilustrującym taką właśnie etymologię jest sposób funkcjonowania osiedla Ijburg - Haveneiland-West w Amsterdamie. (Rys. 2) Mimo zadeklarowanych pro ekologicznych postaw w projektowaniu i funkcjonowaniu osiedla zwierzęta domowe nie mają tu wstępu na większość terenów zieleni urządzonej. Jednak w planie pozostawiono pasy ziemi "niczyjej", nieużytki między brzegiem sztucznych wysp, a zabudową mieszkalną, tworząc pole dla eksperymentów funkcjonalnych mieszkańców osiedla. To tu powstały ciągi pieszo-rowerowe $\mathrm{z}$ trasą spacerową dla psów, farmy miejskie, w tym Moes32 oraz place zabaw dla zwierząt i dzieci.

W tym kontekście współczesne przestrzenie międzygatunkowe powstają w miejscach bez konkretnie określonej funkcji lub stanowią element implementowany w już funkcjonujące struktury o przeznaczeniu nie konfliktogennym, nie wywołującym antagonizmów społecznych.

Interakcje międzygatunkowe najczęściej powstają na obszarach o specyficznej genezie i przeznaczeniu. Zachodzący proces najłatwiej zaobserwować w przypadku przestrzeni niczyich, określonych jako miejsca bez ściśle zdefiniowanego podziału własności lub których stan prawny nie jest znany, czy zewidencjonowany.

Interakcje tego typu będą miały również miejsce w wypadku granic pomiędzy terenami o wyraźnie odmiennych funkcjach (np. funkcja mieszkalna, a przemysłowa) . Jest to niewątpliwie konsekwencja wprowadzania do miast konsekwentnego strefowania funkcjonalnego, które na granicach obszarów powoduje powstanie pasa "ziemi niczyjej", zwanej dalej linią demarkacyjną. Jej charakter może być różny w zależności od przyjętego własnościowego lub funkcjonalnego kryterium podziału. Analiza antagonizmów przestrzennych na styku różnych wysegregowanych funkcji w mieście pozwoliła określić kilka potencjalnych miejsc katalizujących tworzenie i utrzymanie rodzaju zagospodarowania noszącego znamiona międzygatunkowości. Tego typu punktem katalizującym staje się powstanie granicy między strefami prywatnymi w miejscach zmiany sposobu użytkowania prze- 
strzennego w miejscu powstania strefy o mieszanym przeznaczeniu lub też na granicy stref publicznych, w miejscach zmiany sposobu użytkowania przestrzeni, gdzie na styku różnych funkcji powstaje strefa o mieszanym przeznaczeniu, np. w miejscu łączenia parków i ciągów zieleni rekreacyjnej. Na styku między przestrzeniami prywatnymi a publicznymi powstają tzw. przestrzeni hybrydowe, natomiast w miejscach posiadających prawnego właściciela, lecz celowo pozostawionych w stanie niezagospodarowanym, lub wykorzystywanych biernie jako zieleń izolacyjna czy ochronna - typowe nieużytki miejskie.
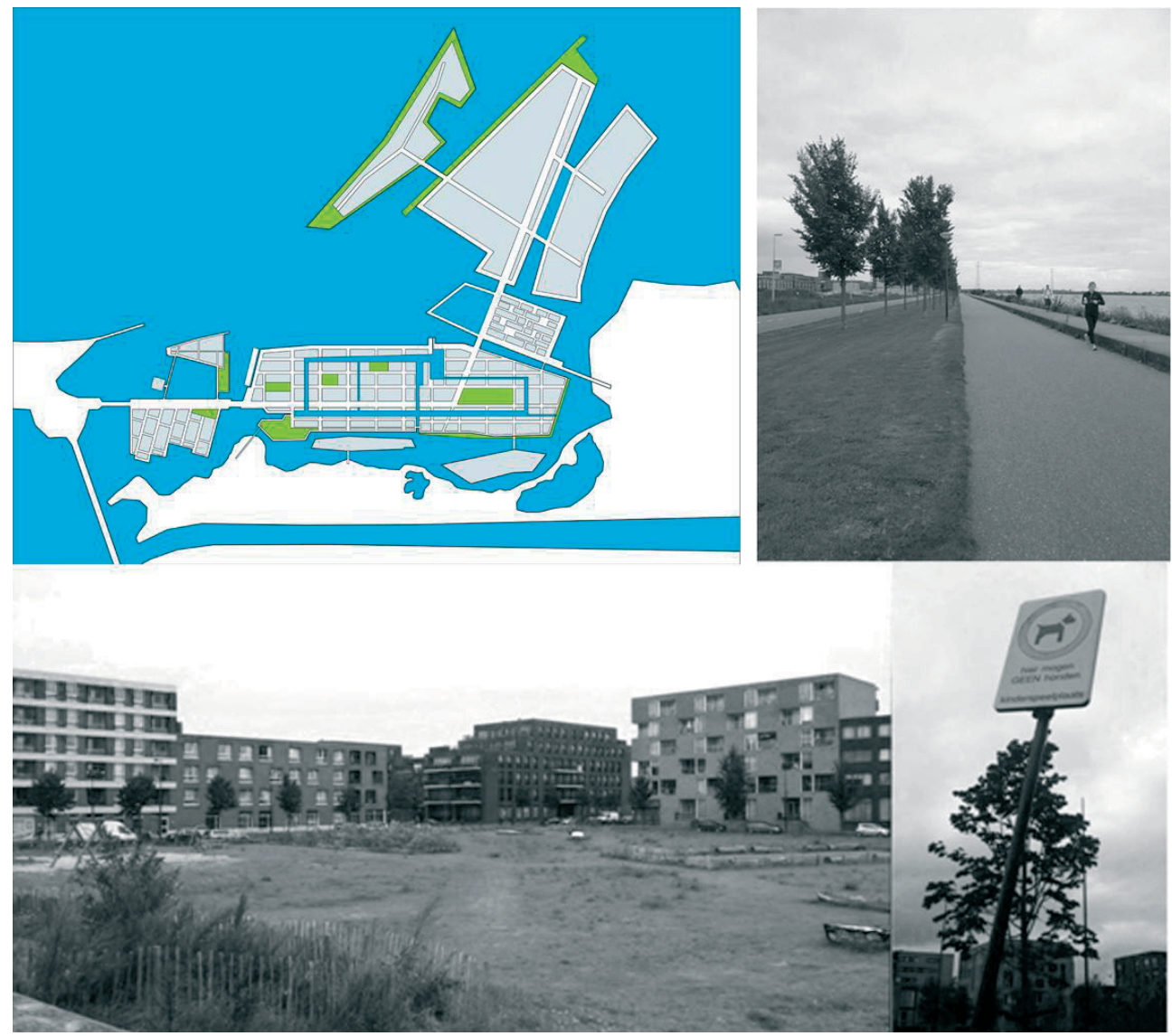

Rys. 2. Przykład pro-ekologicznych rozwiązań w projektowaniu terenów zieleni osiedlowej w dzielnicy Amsterdamu Ijburg - Haveneiland-West, wykluczających lub dopuszczających obecność zwierząt domowych i dzikich

\section{Opis przypadku - Warszawa, Wroclaw, Zielona Góra}

Najlepszymi przykładami implementacji teorii przestrzeni międzygatunkowych w praktyce $\mathrm{w}$ warunkach polskich są działania podejmowane w części dużych miast takich, jak Warszawa czy Wrocław. W niniejszym opracowaniu uwzględniono również Zieloną Górę, jako szczególny i unikalny w skali kraju przypadek specyficzny ze względu na swoją lokalizację oraz strukturę terenów miejskich powiększonych nagle na początku 2015 roku. 


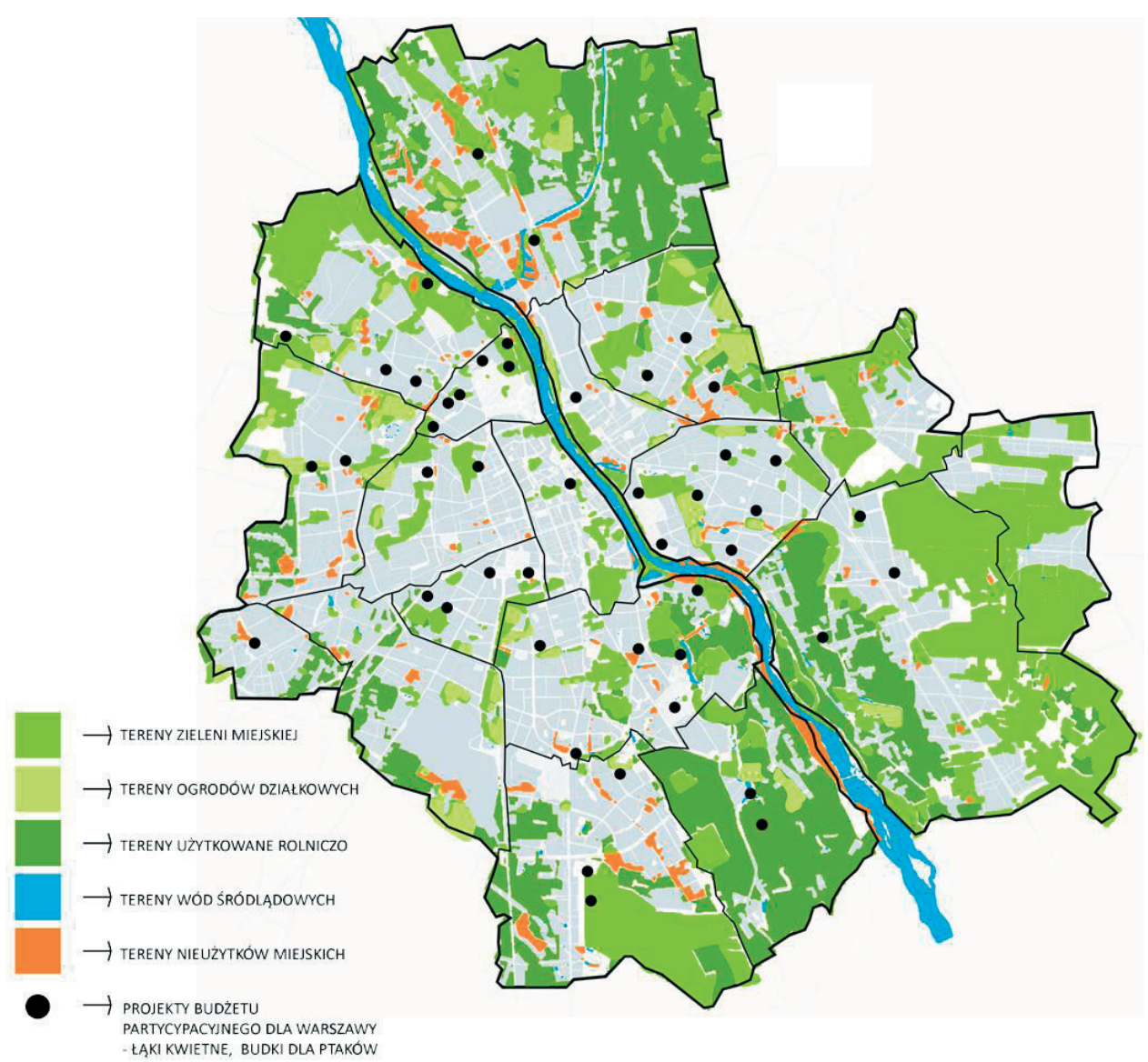

Rys. 3. Rozmieszczenie terenów zieleni w mieście w połączeniu z obszarami nieużytków oraz projektami budżetu partycypacyjnego obejmującego łąki kwietne, budki dla ptaków oraz parki dla psów. Przypadek Warszawy

Warszawa, jako miasto posiada w swoich granicach obszary leśne usytuowane od strony północno-zachodniej zlokalizowane po obu stronach Wisły oraz od strony południowej, jak również zwarte założenie od strony wschodniej. Jak ukazuje poniższy rysunek, oprócz wyraźnie zwartego kompleksu wschodniego zieleń wysoka o charakterze leśnym lub parkowym znajduje się $\mathrm{w}$ dużym rozproszeniu na terenie całego miasta, z zachwianiem owej równomierności od strony zachodniej. (Rys. 3) Podobnie tereny o charakterze rolnym i łąkowym zlokalizowane są w pobliżu kompleksów leśnych na obszarach północnowschodnim oraz południowo-zachodnim, związanym z biegiem rzeki. W wypadku Warszawy istotnym elementem w budowie struktury przestrzeni międzygatunkowych są nieużytki oraz ogrody działkowe, które uzupełniają układ zieleni miejskiej. Na kompletność sytemu przestrzeni międzygatunkowych Warszawy składają się również istniejące ośrodki zooterapii (zwłaszcza hipo- i kynoterapii), parki dla psów oraz elementy powstałe w ramach budżetów obywatelskich. Tegoroczny (stan na 2016 r.) budżet partycypacyjny miasta zawierał szereg projektów związanych z obecnością zwierząt w miastach, co w istotny sposób odróżnia stolicę od reszty kraju. Do głównych inicjatyw należy zakładanie łąk kwietnych jako siedlisk wielu gatunków owadów oraz budowa budek lęgowych dla ptaków w centrum miast. Jak widać większość działalności o tym charakterze skupia się w obrębie śródmieścia, omijając 
istniejące założenia zieleni miejskiej. Co charakterystyczne, układy te mają bardzo niewiele punktów wspólnych, łącząc się częściej z terenami silnie zabudowanymi.

Specyficzny układ zieleni miejskiej Wrocławia sięga czasów XIX - wiecznego układu klinowego. Znacznie większa jej część skupia się wzdłuż brzegów Odry z kierunku północno-zachodniego oraz wschodniego. System ten uzupełniają połączone ze sobą elementu parków, skwerów i ogrodów działkowych. W mieście funkcjonują liczne ośrodki zooterapii, w tym wykorzystujące czasowo tereny nadrzecznych nieużytków. (Rys. 4)

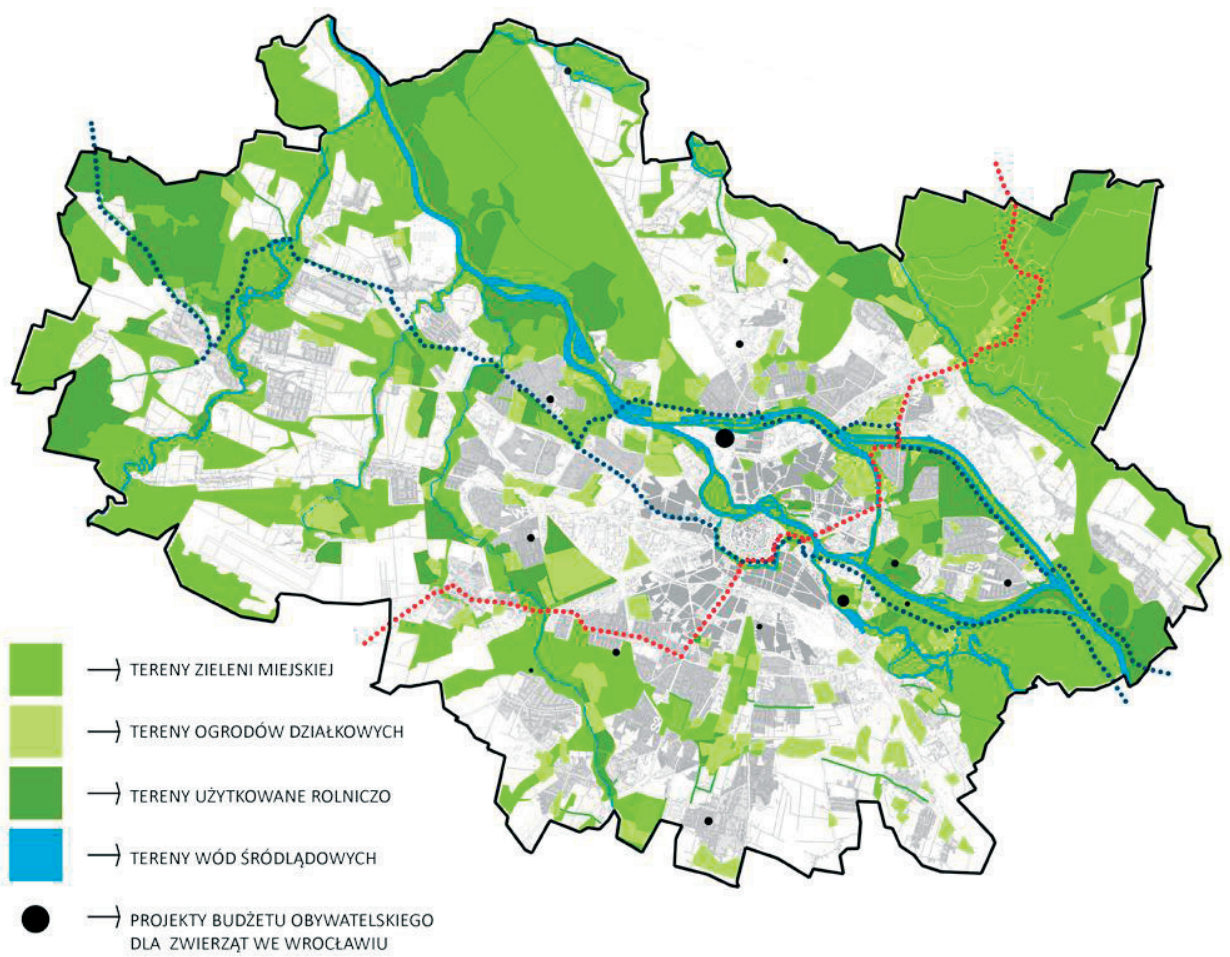

Rys. 4. Rozmieszczenie terenów zieleni w mieście w połączeniu z obszarami nieużytków oraz projektami budżetu partycypacyjnego parki dla psów i ośrodki zooterapii. Przypadek Wrocławia

Przypadek Zielonej Góry jest o tyle szczególny, że powierzchnia miasta uległa znacznemu powiększeniu wraz z wcieleniem w granice miasta gminy wiejskiej Zielona Góra i powstanie aglomeracji od początku 2015 roku. Dotychczas bardzo silnie zalesiona, po prawie pięciokrotnym zwiększeniu swojej powierzchni, Zielona Góra zyskała zwarty pierścień terenów leśnych dookoła tzw. Starego Miasta oraz pasma terenów uprawnych na południowym wschodzie oraz na północy. [11]

Tabela 1. Zmiana struktury zieleni miejskiej aglomeracji zielonogórskiej na przełomie 2014/2015 roku

\begin{tabular}{|c|c|c|c|c|c|c|}
\hline \multirow{2}{*}{\multicolumn{2}{|c|}{$\begin{array}{l}\text { Rok } \\
\text { Powierzchnia ogółem [ha] }\end{array}$}} & \multicolumn{2}{|c|}{2014} & \multicolumn{3}{|c|}{2015} \\
\hline & & 5834 & $100 \%$ & 27832 & & $100 \%$ \\
\hline \multirow{2}{*}{$\begin{array}{l}\text { Powierzchnia } \\
\text { lasów ogółem [ha] }\end{array}$} & $\begin{array}{l}\text { Powierzchni lasów } \\
\text { publicznych [ha] }\end{array}$ & \multicolumn{2}{|c|}{2556,1} & \multicolumn{3}{|c|}{14590,4} \\
\hline & $\begin{array}{l}\text { Powierzchnia lasów } \\
\text { prywatnych [ha] }\end{array}$ & \multicolumn{2}{|c|}{16,3} & \multicolumn{3}{|c|}{350,8} \\
\hline
\end{tabular}


O ile w wypadku innych miast mówimy o nieużytkach w sytuacji głównie terenów czasowego użytkowania lub pozostałych po już nieistniejącej funkcji, o tyle w wypadku Zielonej Góry należy przedefiniować nieco pojęcie nieużytku miejskiego w kontekście zachodzących przemian strukturalnych. Ze względu na bardzo dużą lesistość za tereny "miejsko" nieużyteczne można uznać przede wszystkim tereny łąk i upraw rolnych na glebach niższych kategorii oraz część zalesień bez wprowadzonych dodatkowych funkcji. $[12,14]$ (Rys. 5)

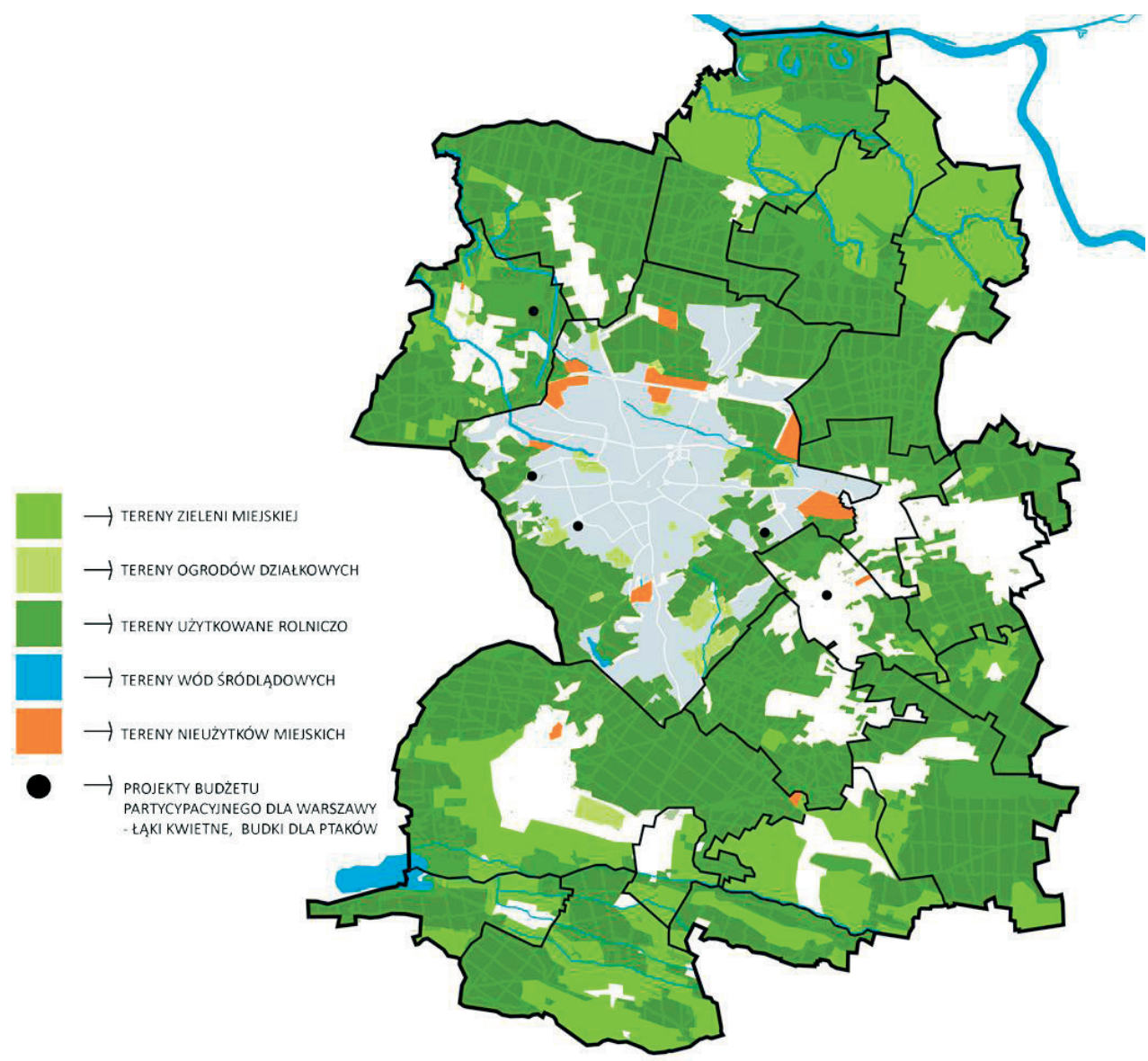

Rys. 5. Rozmieszczenie terenów zieleni w mieście w połączeniu z obszarami nieużytków oraz ośrodkami zooterapii. Przypadek Zielonej Góry

\section{Efekty wprowadzenia}

Zmiany, które zachodzą w strukturach miast pod wpływem wprowadzenia w nie miejsc o charakterze przestrzeni międzygatunkowych można podzielić na kilka kategorii w zależności od strefy oddziaływania relacji człowiek - zwierzę.

Najistotniejszym z nich jest znacznie społeczne, którego głównym wyznacznikiem jest rozwój idei partycypacji społecznej jako formy współtworzenia miasta. Mechanizmy wywierania wpływu społecznego dowodzą roli bezpośredniego zaangażowania w działanie na wzrost poziomu poparcia dla wspieranej inicjatywy oraz konsekwencji w realizacji tak 
wyznaczonego celu. Nie bez znaczenia jest tu również ogólna poprawa dobrostanu człowieka w związku z biernym lub czynnym kontaktem ze zwierzętami i naturą. Istotne ze względu na ogólne dążenie do wprowadzania w życie idei rozwoju zrównoważonego jest otwarcie kanału implementacji zasad rozwoju zrównoważonego poprzez wsparcie (bierne lub czynne) oddolnych inicjatyw mieszkańców w formie indywidualnej lub zorganizowanej, jak w wypadku projektów budżetu obywatelskiego. W tym wypadku wprowadzenie formy parków międzygatunkowych przyczynia się bezpośrednio do wprowadzenia w życie pojęć z zakresu szeroko pojętej ekologii. (Rys. 6)

Aspektem ekonomicznym zachodzącego procesu jest przede wszystkim stworzenie podstawy do powstawania różnych form rolnictwa miejskiego, jako uzupełnienia sieci zieleni miejskiej oraz metody na decentralizację funkcji miejskich. Jest to o tyle istotne, że jednocześnie stwarza możliwość dla samowystarczalności miast poprzez wprowadzenie produkcji żywności oraz możliwości uzyskania przez mieszkańców alternatywnego do typowo miejskich źródła dochodu poprzez wprowadzenie w tego typu przestrzeniach usług odpłatnych takich, jak produkcja żywności, ośrodki terapeutyczne itp.

Zastanowić się należy, jak kształtuje się sytuacja prawna terenów przeznaczonych dla zwierząt w polskich miastach. Jeszcze do niedawna Ustawa o hodowli zwierząt zakazywała wszelkiej hodowli, poza hobbystycznymi, zwierząt takich, jak psy czy koty, na obszarach w granicach administracyjnych polskich miast. Jak jednak pokazywała praktyka, w znacznej części przypadków był to przepis martwy, choć znacznie utrudniający życie mieszkańcom miast, chcącym hodować gołębie, pszczoły czy konie poza terenami wyznaczonymi dla ogrodów zoologicznych i zwierzyńców. Sytuacja nieco się poprawiła wraz z wprowadzeniem zmiany w Ustawie o utrzymaniu czystości i porządku w gminach w 2013 roku, w której to gminy zostały zobowiązane do określenia regulaminu utrzymania czystości i porządku na terenie gminy, a w nim w szczególności

"(...) wymagań utrzymywania zwierząt gospodarskich na terenach wytaczonych z produkcji rolniczej, w tym także zakazu ich utrzymywania na określonych obszarach lub w poszczególnych nieruchomościach (...)", [15]

co stworzyło furtkę dla potencjalnych miejskich rolników, terapeutów czy hobbystów, przenosząc ciężar decyzji bezpośrednio na władze gminne.

Oczywiście nie jest to działanie wystarczające. Niesie ono za sobą konieczność określenia w aktach prawa lokalnego możliwości hodowli takich zwierząt oraz stawiania zabudować służących zwierzętom w miastach. Wymaga to jednak pojawienia się ogólnej świadomości, że takie formy zagospodarowania przestrzeni miast są w ogóle możliwe.

Wprowadzenie w projektowaniu miast pojęcia przestrzeni międzygatunkowych będzie miało największy wpływ na samą funkcjonalność miasta poprzez wprowadzenie nowej funkcji konsekwentnie odchodzącej od założeń segregacji i strefowania miast. Niesie to za sobą konieczność stworzenia bezkonfliktowych przestrzeni dla zwierząt domowych oraz dzikich w miastach, wyboru lokalizacji nieuciążliwych albo taki dobór wprowadzanej funkcji, by stanowiła ona uzupełnienie tej wiodącej na danym terenie. W szerszym kontekście przyczyni się to do rozwoju postaw prosumenckich w miejskiej permakulturze. 

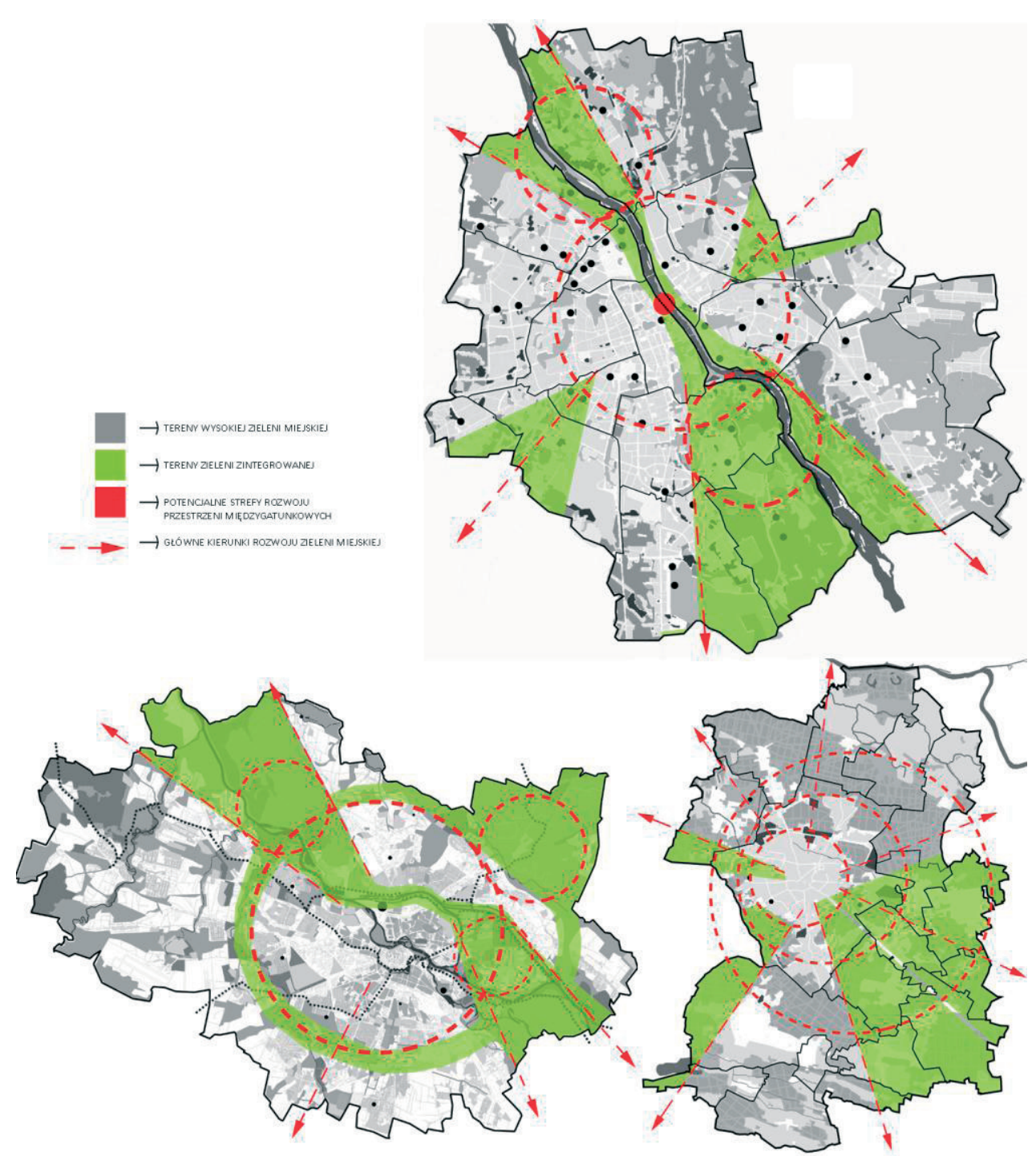

Rys. 6. Analiza możliwości wprowadzenia zamkniętych systemów przestrzeni międzygatunkowych opartych na istniejących układach zieleni leśnej, zieleni uporządkowanej, terenów użytkowanych rolniczo w miastach i elementów zagospodarowania służących zwierzętom w mieście. Główne kierunki rozwoju. Przypadek Warszawy, Wrocławia i Zielonej Góry

\section{Podsumowanie}

Pojawieniu się pojęcia przestrzeni międzygatunkowej towarzyszyło wiele przemian społecznych, kulturowych i ideowych, które umożliwiły przejście od przedmiotowego traktowania zwierząt na terenach zurbanizowanych i pozwoliły na uformowanie się ich podmiotowości. Przejmując pewne pojęcia z zakresu ekologii, filozofii społecznej czy psychologii, stworzona została definicja rozwijająca się coraz dynamiczniej pod różnymi nazwami. Przestrzeń miedzygatunkowa może być rozpatrywana razem z pojęciami takimi, jak animal-aided design [16], polyspecies architecture i wiele innych. 
Tym istotniejsza staje się próba wdrożenia pojęć związanych z szeroko pojętą architekturą integracyjną dla zwierząt i ludzi. Polskie miasta przechodzą teraz proces gwałtownych przemian dostosowujących je do potrzeb wolnego rynku, rosnących potrzeb i wymagań bogacącego się społeczeństwa w zakresie jakości przestrzeni oraz jej funkcjonalności. Odpowiedzią na działania w tym właśnie nurcie, łączącym podwyższone standardy jakościowe z myśleniem pro - ekologicznym jest właśnie to, co obecnie nazywamy projektowaniem przestrzeni międzygatunkowych. Jak pokazują powyższe analizy przestrzenie te mogą w przyszłości stać się jedną z idei przyświecających urbanistom i architektom w świadomym kreowaniu miejsc przeznaczonych dla każdej z żywych istot zamieszkujących tereny miast.

\section{Literatura}

1. Chmielewski J. Teoria urbanistyki w projektowaniu i planowaniu miast. Oficyna Wydawnicza Politechniki Warszawskiej, Warszawa, 2005, 406.

2. Dziewoński K. Geografia osadnictwa i zaludnienia. Dorobek, podstawy teoretyczne i problemy badawcze. Przegląd Geograficzny 28 (1956) 4.

3. Krier L. Architektura wspólnoty. Słowo/obraz/terytoria, Gdańsk, 2011.

4. Szulczewska B., Cieszewska A. Układ przyrodniczy obszaru metropolitalnego: sieć w pierścieniu czy pierścień w sieci? [w:] Żywiołowe rozprzestrzenianie się miast: studia nad zrównoważonym rozwojem, tom 2. (red. Kozłowski S.). Wydawnictwo Ekonomia i Środowisko, Białystok i Warszawa, 2006, 49-70.

5. Encyklopedia PWN, http://encyklopedia.pwn.pl/encyklopedia/, dostęp 01.03.2016.

6. Dodington E.M. Polyspeces park. http://www.expandedenvironment.org/polyspecies-park/, dostęp 10.06.2015.

7. Dodington E.M. How to design with the animal. Constructing posthumanist environments. Master of architecture thesis, ProQuest, UMI Dissertations Publishing, Houston, 2011.

8. Kleszcz J. Zooterapia w przestrzeni miejskiej. Wspótistnienie ludzi i zwierząt. Raporty Katedry Architektury Mieszkaniowej, Przemysłowej, Wnętrz, Ruralistyki, Krajobrazu, Sztuk Wizualnych i Systemów Konstrukcyjnych PWr, seria PRE nr 9. Rozprawa doktorska. Politechnika Wrocławska, Wydział Architektury, Wrocław, 2014, 142.

9. Howard E. Garden cities of to-morrow. Londyn, 1902, przedruk: Osborn F. J., Faber and Faber, Londyn, 1946, 50-57, 138-147.

10. Jansma J.E., Visser A.J., de Wolf P., Stobbelaar D.J. Agromere: how to integrate urban agriculture in the development of the Dutch city of Almere?, 16th IFOAM Organic World Congress, Modena, Włochy, 2008 [za:] http://orgprints.org/view/projects/conference.html, dostęp 01.03.2016.

11. Greinert A., Drozdek M. Zielona Zielona Góra. Strategia rozwoju terenów zieleni w mieście Zielona Góra. Instytut Inżynierii Środowiska Uniwersytetu Zielonogórskiego, Zielona Góra, 2015.

12. Jerzak L., Reda P. Ochrona przyrody w Zielonej Górze do 1945 roku [w:] Historia Zielonej Góry. Tom II. Dzieje miasta w XIX i XX wieku. [red. Strzyżewski W.]. Oficyna Wydawnicza Uniwersytetu Zielonogórskiego, Zielona Góra, 2011. 191-202.

13. Kronenberg J., Bergier T. Wyzwania zrównoważonego rozwoju w Polsce. Fundacja Sendzimira, Kraków, 2010, 245.

14. http://zielonagora.stat.gov.pl/gfx/zielonagora/userfiles/_public/podregiony_2015/podr2015_dzial_xa.pdf, odczyt 01.03.2016.

15. http://isap.sejm.gov.pl/DetailsServlet?id=WDU20130001399, odczyt 01.03.2016.

16. Hauck T., Weisser W. AAD Animal aided - design. Technische Universitat Munchen, 2015. 


\title{
Urban wasteland arrangement as an polyspeces area - effects of implementation - the analysis
}

\author{
Justyna Kleszcz \\ Department of Architecture and Urban Planning, \\ Faculty of Civil Engineering, Architecture and Environmental Engineering, \\ University of Zielona Góra, e-mail:j.kleszcz@aiu.uz.zgora.pl
}

\begin{abstract}
Urban wasteland areas are being formed in two ways. They can be a part of extensively used areas basing on different etymology or, what is more important, a form of artefacts remaining after extinct function. This nascent land, between space of different use, represents the quality or mediocrity of the bordering lines between things planned in the city and those areas left and developing beside without specified plan. Additionally, lack of wasteland's arrangement causes functional, compositional and aesthetical division. With this reason the main purpose of the research is to analyze potential locations of land, which could, in the future, be used to make urban space left without any formal management more coherent and its temporary adaptation for recreational, integrative or educational purposes to be used by inhabitants - both human and animal. Moreover the implementation of idea of polyspecies areas as a form of actual solution, a method of transforming problematic urban areas, will have an influence on changing the way of city functioning as a living body, ecosystem and urban structure. This way of forming space cumulates positive features of urban transformations - building quality of green recreation areas, sports grounds, the increase of safety, recreating urban flora and fauna and much more.
\end{abstract}

Keywords: polyspecies area, urbanism, animal architecture, town planning, urban green areas. 